\title{
The effect of zinc deficiency and iron overload on endocrine and exocrine pancreatic function in children with transfusion-dependent thalassemia: a cross-sectional study
}

\author{
Suzan O. Mousa ${ }^{1 *}$, Ebtihal M. Abd Alsamia ${ }^{1}$, Hend M. Moness ${ }^{2}$ and Osama G. Mohamed ${ }^{1}$
}

\begin{abstract}
Background: Children with transfusion-dependent thalassemia (TDT) suffer from secondary hemosiderosis and the delirious effects this iron overload has on their different body organs, including the pancreas. They are also more prone to develop zinc deficiency than the general pediatric population. This study aimed to determine the effect of zinc deficiency and iron overload on the endocrine and exocrine pancreas in TDT children.

Methods: Eighty children, already diagnosed with TDT, were included in this study. We assessed the following in the participant children: serum ferritin, serum zinc, endocrine pancreatic function (oral glucose tolerance test (OGTT), fasting insulin level and from them, HOMA-IR was calculated), and exocrine pancreatic function (serum lipase and serum amylase).

Results: Forty-four TDT children had a subnormal zinc level, while 36 of them had a normal serum zinc level. TDT children with low serum zinc had significantly more impaired endocrine pancreatic function and an abnormally high serum lipase than children with normal serum zinc, $p<0.05$ in all. Serum zinc was significantly lower in TDT children with serum ferritin above the ferritin threshold $(\geq 2500 \mathrm{ng} / \mathrm{ml})$ than those below $(59.1 \pm 20.2 \mathrm{vs} .77 .5 \pm 28.13), p=0.02$. TDT children, having a serum ferritin $\geq 2500 \mathrm{ng} / \mathrm{ml}$, had significantly more frequently impaired endocrine pancreatic function and abnormally high serum lipase than TDT children below the ferritin threshold, $p<0.05$ in all.
\end{abstract}

Conclusion: In children with transfusion-dependent thalassemia, zinc deficiency aggravates iron-induced pancreatic exocrine and endocrine dysfunction.

Keywords: Transfusion-dependent thalassemia, Zinc deficiency, iron overload, Endocrine pancreas, Exocrine pancreas

\section{Background}

B-thalassemia is a heterogeneous autosomal recessive hereditary anemia, that is caused by either reduced $\left(\Omega^{+}\right)$ or absent $\left(B^{0}\right)$ synthesis of the $\beta$-globin chains of the

*Correspondence: suzanmousa@mu.edu.eg

1 Pediatric Department, Children's University hospital, Faculty of Medicine, Minia University, El-Minya, Egypt

Full list of author information is available at the end of the article hemoglobin. The reduced or absence of $\beta$-globin chains result in a relative excess of unbound $\alpha$-globin chains, which precipitate in erythroid precursors in the bone marrow leading to their premature death and ineffective erythropoiesis [1].

Transfusion-dependent thalassemia (TDT), previously known as thalassemia major, causes severe anemia with several health problems like enlarged spleen, bone deformities, iron overload, hepatitis infection, and 
requires regular life-long transfusion therapy and medical supervision $[2,3]$.

The increased plasma circulating non-transferrinbound iron (NTBI) species cause iron overload-induced organ dysfunction and is implicated in cellular dysfunction, and cytotoxicity [4]. The unbound iron, together with the chronic hypoxia due to anemia, potentiates iron's toxic effect on the endocrine glands in patients with thalassemia [5].

Studies have documented endocrine pancreas dysfunction in patients with thalassemia $[6,7]$, but little has been published about the alterations of the exocrine pancreas in thalassemia.

Chronic blood transfusion in thalassemia changes the micronutrient status [8]. One of the most critical micronutrients deficiencies patients with thalassemia suffer from is zinc, which is an essential trace element in animal and human nutrition and well established in the synthesis of cholesterol, protein, and fats [9]. For multiple reasons, hemoglobinopathies and thalassemia patients are prone to zinc deficiency [10].

Adding to the nutritional obstacles contributing to zinc deficiency in children of developing countries in general $[11,12]$, factors contributing to zinc deficiency in thalassemia, in particular, are impaired utilization and excessive losses through ongoing hemolysis and the usage of iron chelators [13-15]. Previous studies reported that deferoxamine and deferiprone might contribute to $\mathrm{Zn}$ deficiency in thalassemia, eliminating positive divalent ions, like iron and $\mathrm{Zn}$, into the urine $[16,17]$.

Few studies reported the effect of zinc deficiency on the endocrine pancreas, but its effect on exocrine pancreatic function had not been widely studied as low levels of zinc in the blood plasma affect the islets of Langerhans secretion and production of insulin. Zinc also plays an important role in forming insulin crystals and the release and transportation of insulin [18]. Moreover, supplementation of zinc to type 2 diabetes patients improved their symptoms of diabetes because it decreases the level of cholesterol and HbA1c levels in the blood $[19,20]$.

This study aimed to determine the effect of zinc deficiency and iron overload on the endocrine and exocrine function of the pancreas in children with transfusion-dependent thalassemia (TDT) who have secondary hemosiderosis.

\section{Methods}

\section{Subjects}

This cross-sectional study was carried out at the pediatric department, Faculty of Medicine, Minia University, from January 2017 till December 2019. We included in this study 80 children already diagnosed with transfusiondependent thalassemia (TDT). They were recruited from the Pediatric hematology outpatient clinic and inpatient unit.

Included children were on regular monthly or bimonthly blood transfusion programs (transfusiondependent). Their age was $\geq 5$ years.

Children with a history of chronic illness other than thalassemia or a change in chelation therapy drug in the last 6 months before participating in the study were excluded.

\section{Baseline clinical assessment}

All included children were subjected to detailed medical history taking and thorough clinical examination with special emphasis on history of the age of the first transfusion, transfusion burden/year $(\mathrm{ml} / \mathrm{kg} /$ year), history of splenectomy, the average frequency of transfusion, and type and duration of chelation therapy.

\section{Laboratory analysis}

The following laboratory investigations were done for all participants: serum ferritin (mean serum ferritin for each case was calculated from serum ferritin at the time of research and those of the previous year from records), serum zinc $(\mathrm{Zn})$, endocrine pancreatic function (Oral glucose tolerance test (OGTT), fasting insulin level and from them, homeostatic model assessment of insulin resistance (HOMA-IR) was calculated) and exocrine pancreatic function (serum lipase and serum amylase).

From each participant child, we collected $5 \mathrm{ml}$ of venous blood samples and put them on serum separator gel tubes. They were allowed to clot for $30 \mathrm{~min}$ at $37^{\circ} \mathrm{C}$ before centrifugation for $15 \mathrm{~min}$ at $3500 \mathrm{rpm}$. The expressed serum was used for measurement of serum ferritin and remaining serum was stored at $-20^{\circ} \mathrm{C}$ for the other investigations.

Serum zinc was assayed by the colorimetric method (Greiner Diagnostic GmbH, Germany). A normal zinc level range was considered between $63.8-110 \mu \mathrm{g} \backslash \mathrm{dl}$. Both serum lipase and serum amylase were measured by enzymatic colorimetric assay according to the IFCC-method (Biomed diagnostic, EGY- CHEM for lab technology, for both parameters). Reference values of lipase at $37^{\circ} \mathrm{C}$ was $\leq 38 \mathrm{u} \backslash \mathrm{L}$, while the reference value for serum amylase at $37^{\circ} \mathrm{C}$ was between 53 and $123 \mathrm{IU} \backslash \mathrm{ml}$. Serum insulin was assayed by Insulin Human EIA Kit, abcam, ab100578. Fasting insulin levels below ten $\mu \mathrm{IU} / \mathrm{L}$ were considered normal [21].

For OGTT, Blood samples for blood glucose were measured at fasting and every half an hour for $2 \mathrm{~h}$ (five samples were obtained). Results of the OGTT was graded on NIH criteria: a 2-h glucose level below 140 was considered normal; between 140 and 200, impaired glucose tolerance; and greater than 200, diabetes mellitus [22]. 
HOMA-IR was calculated according to the following equation: HOMA-IR = fasting insulin $\mathbf{u I U} / \mathbf{m L} \mathrm{X}$ fasting glucose $(\mathrm{mg} / \mathrm{dl}) \backslash 405$. HOMA-IR above 1.9 indicated early insulin resistance [23].

The enrolled TDT children were then grouped into two groups; first according to their serum zinc level into low serum zinc group (serum zinc $<63.8 \mu \mathrm{g} \backslash \mathrm{dl}$ ) and normal serum zinc group (serum zinc $\geq 63.8 \mu \mathrm{g} \backslash \mathrm{dl}$ ). Then, we grouped the children according to their serum ferritin level into the first group with serum ferritin $\geq 2500 \mathrm{ng} / \mathrm{ml}$ and the second with serum ferritin $<2500 \mathrm{ng} / \mathrm{ml}$.

\section{Statistical analysis}

Data were analyzed using SPSS (statistical package for the social science) version 21 (SPSS Inc., Chicago, Illinois, USA). Quantitative variables were described as mean and standard deviation (SD). Qualitative data were expressed as frequency and percentage.

For the comparison of means, unpaired independent sample student $\mathrm{t}$-test was used. For the comparison of qualitative variables, chi-square test was used. Correlation between two quantitative variables was done by using Pearson's correlation coefficient. Simple logistic and multivariate regression analyses were done for abnormal serum zinc and serum ferritin levels to determine their odds ratios for exocrine and endocrine pancreatic dysfunction. $p$-value of $<0.05$ was considered significant.

\section{Results}

The demographic and clinical data of all the studied TDT children are represented in Table 1. Forty-four TDT children had a subnormal zinc level, they were 21 (47.7\%) males and 23 (52.3\%) females, their mean age was $11.7 \pm 3.7$ years. While 36 TDT children had a normal serum Zn level, 19 (52.8\%) were males, and 17 (47.2\%) were females, with a mean age of $10.7 \pm 2.7$ years. There

Table 1 Demographic and clinical data of the studied TDT children

\begin{tabular}{ll}
\hline Variable & $\mathbf{N = \mathbf { 8 0 }}$ \\
\hline Age of start transfusion (years): Mean \pm SD & $2.2 \pm 2.7$ \\
Duration of transfusion (years): Mean \pm SD & $9.3 \pm 5.02$ \\
BMI: Mean \pm SD & $16.6 \pm 3.02$ \\
Iron chelation therapy: & \\
Deferoxamine: $\mathrm{n}(\%)$ & $23(28.75 \%)$ \\
Deferasirox: $\mathrm{n}(\%)$ & $23(28.75 \%)$ \\
Deferiprone: $\mathrm{n}(\%)$ & $9(11.25 \%)$ \\
Combined: $\mathrm{n}(\%)$ & $25(31.25 \%)$ \\
Splenectomy: $\mathrm{n}(\%)$ & $18(45 \%)$ \\
Hepatomegaly:: $\mathrm{n}(\%)$ & $49(61.25 \%)$ \\
\hline
\end{tabular}

were no statistically significant differences between the two groups regarding age and sex.

On performing OGTT, TDT children with low serum zinc had significantly more frequently impaired glucose tolerance tests than cases with normal serum zinc, with an odds ratio of 6.4 (95\% CI: 1.3-30.7). Also, they had significantly more frequently abnormally high HOMAIR than cases with normal serum zinc. The odds ratio of high HOMA-IR was 4.2 (95\% CI: 1.08-16.6).

Regarding pancreatic exocrine function, serum lipase was significantly higher in TDT children with low serum zinc than those with normal serum zinc. Also, TDT children with low serum zinc had significantly more frequently abnormally high serum lipase than TDT children with normal serum zinc, with an odds ratio of 9.6 (95\% CI: 2.9-31.8) (Table 2).

When we compared serum ferritin of the two groups, we found that TDT children with low zinc had significantly higher serum ferritin $(4780.36 \pm 3974.02 \mathrm{ng} /$ $\mathrm{ml}$ ) than TDT children with normal serum zinc level $(2895.44 \pm 2739.65 \mathrm{ng} / \mathrm{ml})$, as $p=0.008$. We demonstrated the correlations between serum zinc and serum ferritin in the two groups (Fig. 1).

Moreover, 29 (65.9\%) of the TDT children with low zinc had serum ferritin above the $2500 \mathrm{ng} / \mathrm{ml}$ threshold. This was significantly more frequent than children with normal serum zinc, as only 14 (38.9\%) of them had serum ferritin above the threshold.

Serum zinc was significantly lower in TDT children with serum ferritin above the ferritin threshold than those with serum ferritin below $(59.1 \pm 20.2$ vs. $77.5 \pm 28.13)$, as $p=0.02$.

When we compared the pancreatic functions of the TDT children according to their ferritin status i.e., having serum ferritin above or below ferritin threshold, which is equal to $2500 \mathrm{ng} / \mathrm{ml}$. TDT children, having a serum ferritin $\geq 2500 \mathrm{ng} / \mathrm{ml}$, had significantly more frequently impaired oral glucose tolerance test than TDT children below the ferritin threshold, with an odds ratio of 1.4 (95\% CI: 0.4-4.5). Also, they had significantly more frequently abnormally high fasting insulin levels than TDT children below the ferritin threshold, with an odds ratio of 4.2 (95\% CI: 1.08-16.6). Regarding pancreatic exocrine function, serum lipase was significantly more frequently abnormally high in TDT children having serum ferritin above ferritin threshold than those with serum ferritin below ferritin threshold, with an odds ratio of 4 (95\% CI: 1.5-10.8). (Table 3).

Pearson's correlation revealed that serum zinc had significant negative correlations with both serum lipase $(\mathrm{r}=-0.48, p=0.2)$ and serum ferritin $(\mathrm{r}=-0.38, p=0.01)$. Serum ferritin had significant positive correlations with OGTT $(r=0.31, p=0.005)$, 
Table 2 Endocrine and exocrine pancreatic functions in TDT children according to their zinc status

\begin{tabular}{|c|c|c|c|c|}
\hline Variables & $\begin{array}{l}\text { Low serum zinc } \\
N=44\end{array}$ & $\begin{array}{l}\text { Normal serum zinc } \\
N=36\end{array}$ & $\mathrm{p}$ & Odds ratio $(95 \% \mathrm{Cl})$ \\
\hline \multicolumn{5}{|c|}{ I. Endocrine pancreatic function } \\
\hline \multicolumn{5}{|l|}{ 1) OGTT } \\
\hline Impaired: n (\%) & $12(27.3 \%)$ & $2(5.6 \%)$ & $0.01 *$ & $6.4(1.3-30.7)$ \\
\hline \multicolumn{5}{|c|}{ 2) Insulin ( $\mu \mathrm{lu} / \mathrm{ml})$ : } \\
\hline Mean $\pm S D$ & $15.4 \pm 0.7$ & $12.6 \pm 5.8$ & 0.4 & \\
\hline High: n (\%) & $32(72.7 \%)$ & $16(44.4 \%)$ & 0.07 & $0.88(0.7-1.04)$ \\
\hline \multicolumn{5}{|l|}{ 3) HOMA-IR } \\
\hline Mean $\pm S D$ & $3.32 \pm 3.37$ & $2.7 \pm 1.55$ & 0.4 & \\
\hline High: n (\%) & $24(54.5 \%)$ & $8(22.2 \%)$ & $0.03 *$ & $4.2(1.08-16.6)$ \\
\hline \multicolumn{5}{|c|}{ II. Exocrine pancreatic function } \\
\hline \multicolumn{5}{|c|}{ 1) Serum amylase (lu/ml): } \\
\hline Mean $\pm S D$ & $61.95 \pm 16.69$ & $61.13 \pm 20.8$ & 0.8 & \\
\hline Low: n (\%) & $14(31.8 \%)$ & $12(33.3 \%)$ & 0.1 & $0.79(0.21-2.9)$ \\
\hline \multicolumn{5}{|c|}{ 2) Serum lipase (u/l): } \\
\hline Mean $\pm S D$ & $40.23 \pm 9.91$ & $31.75 \pm 4.9$ & $<0.001 *$ & \\
\hline High: n (\%) & $24(54.5 \%)$ & $4(11.1 \%)$ & $<0.001^{*}$ & $9.6(2.9-31.8)$ \\
\hline
\end{tabular}

$\mathrm{Cl}$ confidence interval; OGTT Oral glucose tolerance test; HOMA-IR Homeostatic model assessment of insulin resistance

* Statistical significance $<0.05$

fasting insulin level $(\mathrm{r}=0.39, p=0.005)$, HOMAIR $(\mathrm{r}=0.43, p=0.006)$, and serum lipase $(r=0.33$, $p=0.003)$.

Multiple regression analysis was done to study the effect of having abnormal serum zinc and serum ferritin level as a risk factor for exocrine and endocrine pancreatic dysfunction. Regarding the exocrine pancreatic function expressed by serum amylase and serum lipase. Patients with low zinc levels had the odds of 23.3 times to have high serum lipase more than those with normal serum zinc levels. Also, patients with high serum ferritin levels had the odds of 3.6 times to have high serum lipase, but this did not reach statistical significance in this study. There were no significant effects of serum zinc nor serum ferritin on serum amylase. (Table 4).

For the pancreatic endocrine dysfunction, patients with low serum zinc had the odds of 3.9 times to have an abnormal HOMA-IR more than those with normal serum zinc. Moreover, patients with low serum zinc levels had odds of 6.3 times to have impaired OGTT and odds of 2.1 times to have high fasting insulin, but both odds ratios were not statistically significant.

Nevertheless, patients with high serum ferritin levels had odds of 1.5 times to have an abnormal HOMA-IR and 1.6 times to have a high fasting insulin level. However, again, these two odds ratios did not reach statistical significance in this study (Table 4).

\section{Discussion}

This study aimed to study the effect of zinc deficiency and iron overload on the pancreatic functions in children with transfusion-dependent thalassemia.

We compared the endocrine pancreatic functions in TDT children according to their zinc level; we found that impaired glucose tolerance tests and increased insulin resistance were more frequent in TDT children with zinc deficiency. Many researchers studied the relationship between glucose metabolism and zinc level in thalassemia; they showed that impaired glucose metabolism and low serum zinc levels were common among patients $[24,25]$. Furthermore, another study on patients with thalassemia showed that a decline in serum zinc was associated with a consistent impairment in glucose tolerance test [14].

Zinc deficiency, in general, was linked to insulin resistance. An Australian study on adults with prediabetes showed that higher zinc levels were associated with decreased insulin resistance [26], and serum zinc was negatively associated with insulin resistance in another study on non-diabetics [27]. Adding to the previous studies, cross-sectional analyses reported that children with lower serum zinc concentrations and low dietary zinc intakes have significantly higher serum insulin concentrations and insulin resistance indexes [28-30].

A recent study by Ravi Kant et al. demonstrated that increasing zinc levels improves pancreatic function in 

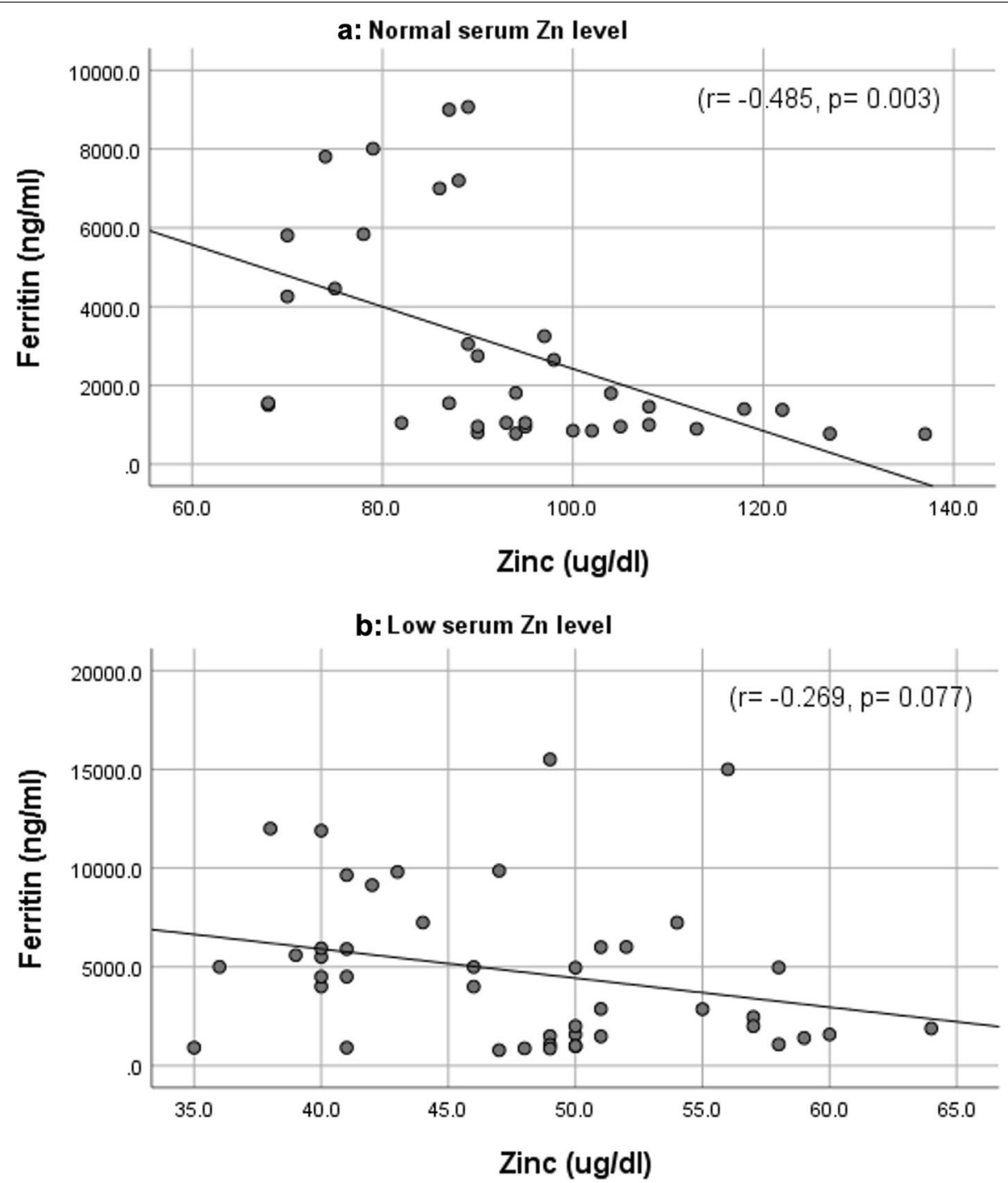

Fig. 1 Scatter plots showing correlations between serum zinc and serum ferritin: a among TDT children with normal serum zinc and $\mathbf{b}$ among TDT children with low serum zinc

normoglycemic adults and decreases insulin resistance in prediabetic adults. Since zinc has been shown to play an essential role in both insulin secretion and insulin action, it is not surprising that zinc levels affect both pancreatic function and insulin resistance [31]. These data agree with the recommendations of De Sanctis and his study group in 2016. They recommended serum zinc levels to be monitored in patients with thalassemia major, as it provides valuable complementary information regarding glucose metabolism [6].

Regarding pancreatic exocrine function, zinc-deficient TDT children had higher mean serum lipase and had more frequently an abnormally high serum lipase (>38 U/L) than TDT children with normal serum zinc.
The relation of zinc deficiency with exocrine pancreatic dysfunction may be less clear than its relationship with endocrine pancreatic function, as there is no clear data on whether zinc deficiency aggravates or results from chronic pancreatitis. On the one hand, micro-and macronutrients and several other nutritional deficiencies were found in subjects with chronic pancreatitis, including lipid-soluble vitamins A, D, E, and K, zinc, and others [32]. Moreover, in patients with chronic pancreatitis, erythrocyte and serum zinc levels were reported to be significantly lower [33, 34]. On the other hand, zinc deficiency may modulate pancreatic digestive enzyme activity by decreasing transporter protein $\mathrm{ZnT} 2$ expression. This transporter protein has been implicated in zinc 
Table 3 Pancreatic functions and zinc level of TDT children according to their ferritin threshold

\begin{tabular}{|c|c|c|c|c|}
\hline Variables & $\begin{array}{l}\text { Serum ferritin }<2500(\mathrm{ng} / \mathrm{ml}) \\
N=40\end{array}$ & $\begin{array}{l}\text { Serum ferritin } \geq 2500(\mathrm{ng} / \mathrm{ml}) \\
N=40\end{array}$ & $p$ & Odds ratio $(95 \% \mathrm{Cl})$ \\
\hline \multicolumn{5}{|c|}{ I. Endocrine pancreatic function } \\
\hline \multicolumn{5}{|l|}{ 1) OGTT } \\
\hline Impaired: n (\%) & $6(15 \%)$ & $8(20 \%)$ & $0.02 *$ & $1.4(0.4-4.5)$ \\
\hline \multicolumn{5}{|c|}{ 2) Insulin $(\mu \mathrm{lu} / \mathrm{ml})$ : } \\
\hline Mean $\pm S D$ & $12.9 \pm 10.9$ & $14.35 \pm 10.68$ & 0.6 & \\
\hline High: n (\%) & $16(40 \%)$ & $32(80 \%)$ & $0.001 *$ & $4.2(1.08-16.6)$ \\
\hline \multicolumn{5}{|l|}{ 3) HOMA-IR } \\
\hline Mean $\pm S D$ & $2.71 \pm 2.29$ & $3.1 \pm 2.58$ & 0.6 & \\
\hline High: n (\%) & $18(45 \%)$ & $14(35 \%)$ & 0.1 & $0.7(0.3-1.6)$ \\
\hline \multicolumn{5}{|c|}{ II. Exocrine pancreatic function } \\
\hline \multicolumn{5}{|c|}{ 1) Serum amylase (lu/ml): } \\
\hline Mean $\pm S D$ & $57.55 \pm 16.97$ & $64.85 \pm 18.81$ & 0.2 & \\
\hline Low: n (\%) & $14(35 \%)$ & $12(30 \%)$ & 0.07 & $0.8(0.3-2)$ \\
\hline \multicolumn{5}{|c|}{ 2) Serum lipase (u/l): } \\
\hline Mean $\pm S D$ & $40.23 \pm 9.91$ & $38.6 \pm 8.5$ & $0.03 *$ & \\
\hline High: n (\%) & $8(20 \%)$ & $20(50 \%)$ & $0.005^{*}$ & $4(1.5-10.8)$ \\
\hline
\end{tabular}

$\mathrm{Cl}$ confidence interval; OGTT Oral glucose tolerance test; HOMA-IR Homeostatic model assessment of insulin resistance

* Statistical significance $<0.05$

Table 4 Multivariate regression analysis of the effect of abnormal serum zinc and serum ferritin on exocrine and endocrine pancreatic function in TDT children

\begin{tabular}{|c|c|c|c|c|c|}
\hline & & \multirow[t]{2}{*}{ Odds ratio } & \multicolumn{2}{|c|}{$95 \% \mathrm{Cl}$ of OR } & \multirow[t]{2}{*}{$p$} \\
\hline & & & Lower & Upper & \\
\hline \multicolumn{6}{|l|}{ Exocrine function } \\
\hline \multirow[t]{2}{*}{ - Amylase } & Zinc & 0.605 & 0.15 & 2.3 & 0.4 \\
\hline & Ferritin & 0.879 & 0.22 & 3.4 & 0.8 \\
\hline \multirow[t]{2}{*}{ - Lipase } & Zinc & 23.378 & 2.50 & 218.4 & $0.006^{*}$ \\
\hline & Ferritin & 3.651 & 0.69 & 19.1 & 0.1 \\
\hline \multicolumn{6}{|c|}{ Endocrine function } \\
\hline \multirow[t]{2}{*}{ - OGTT } & Zinc & 6.310 & 0.66 & 59.8 & 0.1 \\
\hline & Ferritin & 1.053 & 0.18 & 5.9 & 0.9 \\
\hline \multirow[t]{2}{*}{ - HOMAIR } & Zinc & 3.9 & 0.99 & 15.7 & $0.04^{*}$ \\
\hline & Ferritin & 1.5 & 0.38 & 6.07 & 0.5 \\
\hline \multirow[t]{2}{*}{ - Fasting Insulin } & Zinc & 2.1 & 0.9 & 7.3 & 0.07 \\
\hline & Ferritin & 1.667 & 0.087 & 31.869 & 0.2 \\
\hline
\end{tabular}

Cl confidence interval; OR Odds ratio; OGTT Oral glucose tolerance test; HOMA-IR Homeostatic model assessment of insulin resistance.

* Statistical significance $<0.05$

transport into zymogen granules of the exocrine pancreas for the metallation of digestive proenzymes [35, 36]. Additionally, experimental studies strongly correlated zinc deficiency with pancreatic function and structure, as rats' long-term feeding a zinc-deficient diet resulted in pancreatic acinar cell degeneration $[37,38]$.
TDT children with low serum zinc had significantly higher serum ferritin than those with normal serum zinc. Iron overload leads to overproduction of free radicles aggravating oxidative stress, which alters the levels of antioxidant enzymes in serum, causing zinc and other trace elements deficiency [39]. Additionally, increased iron can inhibit zinc absorption in the gastrointestinal tract because iron and zinc compete for the transferrin binding sites in blood and inhibit each other absorption - moreover, iron chelators in patients with thalassemia chelates zinc and other essential minerals besides iron [15].

This study found serum zinc to have significant negative correlations with both serum lipase and serum ferritin. These correlations go with several studies that found ferritin levels to have significant negative correlations with plasma zinc levels [40-43], which supports that iron overload aggravates zinc deficiency [39]. The negative association of serum zinc with serum lipase confirms that zinc deficiency and pancreatitis have a reciprocal relationship [33, 34].

Previous studies had set serum ferritin $\geq 2500 \mathrm{ng} /$ $\mathrm{ml}$ as a threshold above which cardiac, and many iron overload-related organ dysfunctions are aggravated. Serum ferritin can reliably predict cardiac siderosis and endocrine disease in thalassemia when equal to or above $2500 \mathrm{ng} / \mathrm{ml}$ [44].

When we compared pancreatic functions of TDT children according to their serum ferritin level, cases 
with serum ferritin above the ferritin threshold had higher first-hour blood glucose and had more frequently impaired OGTT and high fasting insulin levels than cases with a serum ferritin below ferritin threshold. Excessive iron deposition in the pancreas leads to abnormal glucose metabolism $[45,46]$. as iron overload-generated oxidative damage and functional impairment of insulinproducing pancreatic $B$-cells lead to glucose dysregulation [47]. Besides, insulin resistance developed from iron overload-induced hepatic dysfunction [48].

Regarding pancreatic exocrine function relation to serum ferritin level, TDT children with serum ferritin $\geq 2500 \mathrm{ng} / \mathrm{ml}$ had significantly higher serum lipase $(>38 \mathrm{U} / \mathrm{L})$ than TDT children having serum ferritin below this level. Andersson and co-workers suggested that secondary hemochromatosis is one of the toxic factors causing chronic pancreatitis in thalassemia [49]. They attributed that chronic oxidative stress induced by hemochromatosis is toxic to the pancreatic cells [50]. Other studies validated the direct link of iron overload to exocrine and endocrine pancreatic dysfunction through quantitative measuring the pancreatic iron by MRI [51-53].

In this study, zinc deficiency is a significant risk factor for exocrine and endocrine pancreatic dysfunction as zinc is involved in many of these processes within the pancreas, including glucagon secretion, digestive enzyme activity, and insulin packaging, secretion, and signaling. So, zinc deficiency impairs many vital processes of the pancreas leading to exocrine dysfunction and impairment of systemic glycemic control [36], aggravating the iron overload-induced pancreatic injury.

\section{Conclusion}

Zinc deficiency aggravates iron-induced pancreatic exocrine and endocrine dysfunction in children with transfusion-dependent thalassemia. Therefore, we recommend regular serum zinc level monitoring and zinc supplementation in children with TDT, together with robust iron chelation therapy, as this may slow the progression of pancreatic function deterioration in those children. However, further studies are needed to study the effects of zinc supplementation on pancreatic function in TDT children.

\section{Abbreviations}

TDT:Transfusion-dependent thalassemia; OGTT: Oral glucose tolerance test; HOMA-IR: Homeostatic model assessment of insulin resistance; Zn: Zinc.

\section{Acknowledgements}

Not applicable.

\section{Authors' contributions}

OGM, SOM, and HMM participated in the design and planning of the study. HMM has done the lab work. EMA has done the OGTT. In addition, SOM and
EMA participated in data collection, analysis of results, and preparation of drafts of the manuscript. All authors read and approved the final manuscript.

Funding

No external funding.

Availability of data and materials

The datasets analyzed during the current study are available from the corresponding author on reasonable request.

\section{Declarations}

\section{Ethics approval and consent to participate}

This study was approved by the Institutional Review Board and Medical Ethics committee, Faculty of Medicine, Minia University. The study was designed to respect the expected ethical aspects. It was performed according to the Declaration of Helsinki 1975, as revised in 2008. The anonymity and confidentiality of the participants were protected, with avoiding deceptive practice. The participants were given the right to withdraw from our research. We obtained written consent from the participant children's parents or caregivers after explaining the details of the study.

\section{Consent for publication}

The authors declare that the article is original and that its contents have not been published in full or in part. We also would like to declare that the manuscript has been read and approved by all authors.

\section{Competing interests}

All authors declare that they have no conflicts of interest.

\section{Author details}

'Pediatric Department, Children's University hospital, Faculty of Medicine, Minia University, El-Minya, Egypt. ${ }^{2}$ Department of Clinical Pathology, Minia University hospitals, Minia University, El-Minya, Egypt.

Received: 16 June 2021 Accepted: 12 October 2021

Published online: 22 October 2021

\section{References}

1. Elhalfawy K, Daif A, Shaalan O. Detection of common beta thalassemia mutations among Egyptian patients. Egypt J Genet Cytol [Internet]. 2018 Jan 1 [cited 2021 May 3];46(1):111-9. Available from: www.esg.net.eg

2. Tubman VN, Fung EB, Vogiatzi M, Thompson AA, Rogers ZR, Neufeld EJ, et al. Guidelines for the standard monitoring of patients with thalassemia: Report of the thalassemia longitudinal cohort. J Pediatr Hematol Oncol [Internet]. 2015 Apr 7 [cited 2021 May 6];37(3):e162-9. Available from: / pmc/articles/PMC4511957/.

3. Ahmed E, Shaheen M, Amin T, Hamad A, Zughbur MR, Hospital A-S. Prevalence of Hypogonadism in Thalassemia major patients in Gaza strip [Internet]. 2019 [cited 2021 May 6]. Available from: http://dstore.alazhar. edu.ps/xmlui/handle/123456789/1401

4. Andrews NC, Schmidt PJ. Iron homeostasis [Internet]. Vol. 69, Annual Review of Physiology. Annual Reviews; 2007 [cited 2021 May 28]. p. 69-85. Available from: https://www.annualreviews.org/doi/abs/10.1146/ annurev.physiol.69.031905.164337

5. De Sanctis V, Soliman A, Elsedfy H, Skordis N, Kattamis C, Angastiniotis M, et al. Growth and endocrine disorders in thalassemia: The international network on endocrine complications in thalassemia (I-CET) position statement and guidelines. Indian J Endocrinol Metab [Internet]. 2013 [cited 2021 May 28];17(1):8. Available from:/pmc/articles/PMC3659911/.

6. De Sanctis V, Soliman AT, Elsedfy H, Pepe A, Kattamis C, El Kholy M, et al. Diabetes and Glucose Metabolism in Thalassemia Major: An Update [Internet]. Vol. 9, Expert Review of Hematology. Taylor and Francis Ltd; 2016 [cited 2021 May 8]. p. 401-8. Available from: https://www.tandf online.com/doi/abs/10.1586/17474086.2016.1136209

7. Cario H, Holl RW, Debatin KM, Kohne E. Disproportionately elevated fasting proinsulin levels in normoglycemic patients with thalassemia major are correlated to the degree of iron overload. Horm Res [Internet]. 2003 
[cited 2021 May e Available from: https://www.karger.com/Article/FullT ext/68572

8. Claster S, Wood JC, Noetzli L, Carson SM, Hofstra TC, Khanna R, et al. Nutritional deficiencies in iron overloaded patients with hemoglobinopathies. Am J Hematol [Internet]. 2009 Jun 1 [cited 2021 May 28];84(6):344-8. Available from: www.interscience.wiley.

9. Yanagisawa H, Nodera M. Zinc physiology and clinical practice. Biomed Res Trace Elem. 2007;18(1):3-9.

10. Dangi CBS, Kaur M, Singh M. Copper and Zinc Quotient in Haemoglobinopathies. Biomed Pharmacol J [Internet]. 2015 Mar 28 [cited 2021 May 9];4(1):165-73. Available from: https://biomedpharmajournal.org/vol4n o1/copper-and-zinc-quotient-in-haemoglobinopathies/

11. de Benoist B, Darnton-Hill I, Davidsson L, Fontaine O, Hotz C. Conclusions of the Joint WHO/UNICEF/IAEA/IZiNCG interagency meeting on zinc status indicators. In: Food and Nutrition Bulletin [Internet]. United Nations University Press; 2007 [cited 2021 May 4]. Available from: https://journals. sagepub.com/doi/abs/10.1177/15648265070283S306

12. Yakoob MY, Theodoratou E, Jabeen A, Imdad A, Eisele TP, Ferguson J, et al. Preventive zinc supplementation in developing countries: Impact on mortality and morbidity due to diarrhea, pneumonia and malaria [Internet]. Vol. 11, BMC Public Health. BioMed Central; 2011 [cited 2021 May 4]. p. 1-10. Available from: http://www.biomedcentral.com/1471-2458/11/ $\mathrm{S} 3 / \mathrm{S} 23$

13. Fikry SI, Saleh SA, Sarkis NN, Mangoud H. Study of serum zinc in relation to nutritional status among thalassemia patients in Damanhour Medical National Institute. J Egypt Public Health Assoc [Internet]. 2003 Jan 1 [cited 2021 May 4];78(1-2):73-93. Available from: https://europepmc.org/artic $\mathrm{le} / \mathrm{med} / 17219912$

14. Dehshal MH, Hooghooghi AH, Kebryaeezadeh A, Kheirabadi M, Kazemi $\mathrm{S}$, Nasseh A, et al. Zinc deficiency aggravates abnormal glucose metabolism in thalassemia major patients. Med Sci Monit [Internet]. 2007;13(5):CR235-9 [cited 2021 May 4]Available from: https://www. medscimonit.com/abstract/index/idArt/484604.

15. Erdoĝan E, Canatan D, Örmeci AR, Vural H, Aylak F. The effects of chelators on zinc levels in patients with thalassemia major. J Trace Elem Med Biol. 2013:27(2):109-11.

16. Galanello R. Deferiprone in the treatment of transfusion-dependent thalassemia: a review and perspective. Ther Clin Risk Manag [Internet]. 2007 Oct [cited 2021 may 4];3(5):795-805. Available from: http://www. ncbi.n/m.nih.gov/pubmed/18473004.

17. Mehdizadeh M, Zamani G, Tabatabaee S. Zinc status in patients with major $\beta$-thalassemia. Pediatr Hematol Oncol [Internet]. 2008 Jan [cited 2021 May 4];25(1):49-54. Available from: https://www.tandfonline.com/ doi/abs/10.1080/08880010701773738

18. Rungby J. Zinc, zinc transporters and diabetes [Internet]. Vol. 53, Diabetologia. Springer; 2010 [cited 2021 May 3]. p. 1549-51. Available from: https://link.springer.com/article/10.1007/s00125-010-1793-x

19. Basaki M, Saeb M, Nazifi S, Shamsaei HA. Zinc, copper, iron, and chromium concentrations in young patients with type 2 diabetes mellitus. Biol Trace Elem Res [Internet]. 2012 Aug 21 [cited 2021 May 6];148(2):161-4. Available from: https://link.springer.com/article/10.1007/ s12011-012-9360-6

20. Jansen J, Rosenkranz E, Overbeck S, Warmuth S, Mocchegiani E, Giacconi $\mathrm{R}$, et al. Disturbed zinc homeostasis in diabetic patients by in vitro and in vivo analysis of insulinomimetic activity of zinc. J Nutr Biochem. 2012;23(11):1458-66.

21. Summary of Revisions for the 2008 Clinical Practice Recommendations. Diabetes Care [Internet]. 2008 Jan 1 [cited 2021 May 29];31(Supplement 1):S3-4. Available from: https://care.diabetesjournals.org/content/31/ Supplement_1/S3

22. Bartoli E, Fra GP, Schianca GPC. The oral glucose tolerance test (OGTT) revisited. European Journal of Internal Medicine. Elsevier B.V. 2011;22:8-12.

23. Vogeser M, König D, Frey I, Predel HG, Parhofer KG, Berg A. Fasting serum insulin and the homeostasis model of insulin resistance (HOMA-IR) in the monitoring of lifestyle interventions in obese persons. Clin Biochem. 2007 Sep 1;40(13-14):964-8.

24. Fung EB, Gildengorin $G$, Talwar S, Hagar L, Lal A. Zinc status affects glucose homeostasis and insulin secretion in patients with thalassemia. Nutrients [Internet]. 2015 [cited 2021 May 10];7(6):4296-307. Available from: www.mdpi.com/journal/nutrients
25. Mashhadi MA, Sepehri Z, Heidari Z, Kaykhaei MA, Sargazi A, Kohan F, et al. A cross-sectional study of glycemic status and zinc level in patients with Beta-Thalassemia major. Int J Hematol Stem Cell Res [Internet]. 2017 [cited 2021 May 10];11(4):273-80. Available from: http://www.dtu.ox.ac. uk/homacalculator/index.ph

26. Vashum KP, McEvoy M, Milton AH, Islam MR, Hancock S, Attia J. Is serum zinc associated with pancreatic beta cell function and insulin sensitivity in pre-diabetic and normal individuals? Findings from the hunter community study. PLoS One [Internet]. 2014 Jan 8 [cited 2021 May 28];9(1):e83944. Available from: www.plosone.org

27. Ahn BI, Kim MJ, Koo HS, Seo N, Joo NS, Kim YS. Serum zinc concentration is inversely associated with insulin resistance but not related with metabolic syndrome in nondiabetic Korean adults. Biol Trace Elem Res [Internet]. 2014 Jun 19 [cited 2021 May 28];160(2):169-75. Available from: http://www.dtu.ox.ac.uk

28. Ortega RM, Rodríguez-Rodríguez E, Aparicio A, Jiménez Al, López-Sobaler AM, González-Rodríguez LG, et al. Poor zinc status is associated with increased risk of insulin resistance in Spanish children. cambridge.org [Internet]. 2021 [cited 2021 May 28]; Available from: https://doi.org/10. 1017/S0007114511003114.

29. García OP, Ronquillo D, Del M, Caamaño C, Martínez G, Camacho M, et al. Zinc, Iron and Vitamins A, C and E Are Associated with Obesity, Inflammation, Lipid Profile and Insulin Resistance in Mexican School-Aged Children. Nutrients [Internet]. 2013 [cited 2021 May 28];5:5012-30. Available from: www.mdpi.com/journal/nutrients

30. Suliburska J, Cofta S, Gajewska E, Kalmus G, Sobieska M, Samborski W, et al. The evaluation of selected serum mineral concentrations and their association with insulin resistance in obese adolescents. Eur Rev Med Pharmacol Sci [Internet]. 20131 [cited 2021 May 28];17(17):2396-400. Available from: $\mathrm{https}: / /$ europepmc.org/article/med/24065235

31. Kant R, Verma V, Patel S, Chandra R, Chaudhary R, Shuldiner AR, et al. Effect of serum zinc and copper levels on insulin secretion, insulin resistance and pancreatic $\beta$ cell dysfunction in US adults: findings from the National Health and nutrition examination survey (NHANES) 2011-2012. Diabetes res Clin Pract [Internet]. 2021;172:108627. Available from: https://doi.org/10.1016/j.diabres.2020.108627.

32. Sobral-Oliveira MB, Faintuch J, Guarita DR, Oliveira CP, Carrilho FJ. Perfil nutricional de pacientes alcoólatras assintomáticos. Arq Gastroenterol [Internet]. 2011 Apr [cited 2021 May 8];48(2):112-8. Available from: https://pubmed.ncbi.nlm.nih.gov/21709952/

33. Girish BN, Rajesh G, Vaidyanathan K, Balakrishnan V. Zinc status in chronic pancreatitis and its relationship with exocrine and endocrine insufficiency. J Pancreas. 2009;10(6):651-6.

34. Milnerowicz H, Jabłonowska M, Bizoń A. Change of zinc, copper, and metallothionein concentrations and the copper-zinc superoxide dismutase activity in patients with pancreatitis. Pancreas [Internet]. 2009 Aug [cited 2021 May 8];38(6):681-8. Available from: https://journals.lww.com/pancr easjournal/Fulltext/2009/08000/Change_of_Zinc_Copper_and_Metal lothionein.14.aspx

35. Guo L, Lichten LA, Ryu MS, Liuzzi JP, Wang F, Cousins RJ. STAT5-glucocorticoid receptor interaction and MTF-1 regulate the expression of ZnT2 (Slc30a2) in pancreatic acinar cells. Proc Natl Acad Sci U S A [Internet]. 201016 [cited 2021 May 29];107(7):2818-23. Available from: https://www. pnas.org/content/107/7/2818

36. Kelleher SL, McCormick NH, Velasquez V, Lopez V. Zinc in specialized secretory tissues: Roles in the pancreas, prostate, and mammary gland. Adv Nutr [Internet]. 2011 Mar 1 [cited 2021 May 29];2(2):101-11. Available from: https://academic.oup.com/advances/article/2/2/101/4591556

37. Song MK, Adham NF. Role of zinc in treatment of experimental acute pancreatitis in mice. Dig Dis Sci [Internet]. 1989 Dec [cited 2021 May 29];34(12):1905-10. Available from: https://link.springer.com/article/10. 1007/BF01536710

38. Koo SI, Turk DE. Effect of zinc deficiency on the ultrastructure of the pancreatic acinar cell and intestinal epithelium in the rat. J Nutr [Internet]. 19771 [cited 2021 May 28];107(5):896-908. Available from: https://acade mic.oup.com/jn/article/107/5/896/4769091

39. Shazia Q, Mohammad ZH, Rahman T, Shekhar HU. Correlation of oxidative stress with serum trace element levels and antioxidant enzyme status in beta thalassemia major patients: A review of the literature. Vol. 2012, Anemia. 2012. 
40. Bekheirnia MR, Shamshirsaz AA, Kamgar M, Bouzari N, Erfanzadeh G, Pourzahedgilani $N$, et al. Serum zinc and its relation to bone mineral density in $\beta$-thalassemic adolescents. Biol Trace Elem Res [Internet]. 2004 Mar [cited 2021 May 10];97(3):215-24. Available from: https://link.sprin ger.com/article/10.1385/BTER:97:3:215

41. Mahyar A, Ayazi P, Pahlevan A-A, Mojabi H, Sehhat M-R, Javadi A. Zinc and copper status in children with Beta-thalassemia major. Iran J Pediat [Internet]. 2010 Sep [cited 2021 may 10];20(3):297-302. Available from: http://www.ncbi.nlm.nih.gov/pubmed/23056720.

42. El Missiry M, Hussein MH, Khalid S, Yaqub N, Khan S, Itrat F, et al. Assessment of serum zinc levels of patients with thalassemia compared to their siblings. Anemia. 2014;2014.

43. Arijanty L, ... SN-P, 2006 undefined. Relationships between plasma zinc and ferritin with nutritional status in thalassemic children. mail.paediatric aindonesiana.org [Internet]. [cited 2021 May 10]; Available from: https:// mail.paediatricaindonesiana.org/index.php/paediatrica-indonesiana/artic le/download/933/774

44. Krittayaphong R, Viprakasit V, Saiviroonporn P, Wangworatrakul W, Wood JC. Serum ferritin in the diagnosis of cardiac and liver iron overload in thalassaemia patients real-world practice: a multicentre study [Internet]. Vol. 182, British Journal of Haematology. Blackwell Publishing Ltd; 2018 [cited 2021 May 10]. p. 301-5. Available from: https://europepmc.org/article/ $\mathrm{med} / 28543061$

45. Mowla A, Karimi M, Afrasiabi A, De Sanctis V. Prevalence of diabetes mellitus and impaired glucose tolerance in $\beta$-thalassemia patients with and without hepatitis C virus infection. In: Pediatric Endocrinology Reviews [Internet]. 2004 [cited 2021 May 28]. p. 282-4. Available from: https:// europepmc.org/article/med/16462712

46. Gomber S, Dabas A, Bagmar S, Madhu SV. Glucose homeostasis and effect of chelation on $\beta$ cell function in children with $\beta$-thalassemia major. J Pediatr Hematol Oncol. 2018:40(1):56-9.

47. Swaminathan S, Fonseca VA, Alam MG, Shah S V. The role of iron in diabetes and its complications [Internet]. Vol. 30, Diabetes Care. American
Diabetes Association; 2007 [cited 2021 May 28]. p. 1926-33. Available from: http://care.diabetesjournals.org

48. Krisai P, Leib S, Aeschbacher S, Kofler T, Assadian M, Maseli A, et al. Relationships of iron metabolism with insulin resistance and glucose levels in young and healthy adults. Eur J Intern Med. 2016;32:31-7.

49. Andersson R, Tingstedt B, Xia J. Pathogenesis of chronic pancreatitis: A comprehensive update and a look into the future [Internet]. Vol. 44, Scandinavian Journal of Gastroenterology. Taylor \& Francis; 2009 [cited 2021 May 17]. p. 661-3. Available from: https://www.tandfonline.com/doi/abs/ 10.1080/00365520902718739

50. Drews G, Krippeit-Drews P, Duiffer M. Oxidative stress and beta-cell dysfunction [Internet]. Vol. 460, Pflugers Archiv European Journal of Physiology. Springer; 2010 [cited 2021 May 28]. p. 703-18. Available from: https://link.springer.com/article/10.1007/s00424-010-0862-9

51. Au WY, Lam WWM, Chu W, Tam S, Wong WK, Liang R, et al. A T2* magnetic resonance imaging study of pancreatic iron overload in thalassemia major. Haematologica [Internet]. 2008 Jan 1 [cited 2021 May 28];93(1):116-9. Available from: https://haematologica.org/article/view/ 4694

52. Noetzli LJ, Papudesi J, Coates TD, Wood JC. Pancreatic iron loading predicts cardiac iron loading in thalassemia major. Blood [Internet]. 2009 Nov 5 [cited 2021 May 28];114(19):4021-6. Available from: http://ashpublica tions.org/blood/article-pdf/114/19/4021/1318544/zh804509004021.pdf

53. Matter RM, Allam KE, Sadony AM. Gradient-echo magnetic resonance imaging study of pancreatic iron overload in young Egyptian beta-thalassemia major patients and effect of splenectomy. Diabetol Metab Syndr [Internet]. 2010 Apr 15 [cited 2021 May 28];2(1):23. Available from: http:// www.dmsjournal.com/content/2/1/23

\section{Publisher's Note}

Springer Nature remains neutral with regard to jurisdictional claims in published maps and institutional affiliations.
Ready to submit your research? Choose BMC and benefit from:

- fast, convenient online submission

- thorough peer review by experienced researchers in your field

- rapid publication on acceptance

- support for research data, including large and complex data types

- gold Open Access which fosters wider collaboration and increased citations

- maximum visibility for your research: over $100 \mathrm{M}$ website views per year

At BMC, research is always in progress.

Learn more biomedcentral.com/submissions 